\title{
Experiences with USP Apparatus 4 Calibration
}

\author{
Johannes Krämer ${ }^{1,2}$, and Erika Stippler ${ }^{1}$
}

email:jkraemer@phast.de

\section{Introduction}

his paper is a summary of results presented for the system suitability test of the flow through cell apparatus presented at a series of conferences starting with FIP's Dissolution Workshop in Frankfurt, Germany, November 14, 1996, in particular the contribution "Collaborative Studies on Calibration-"The Flow-Through Cell"; J.Krämer, E. Wirbitzki.

Under the chairmanship of Martin Siewert the "Dissolution Working Group" of FIP, now called "FIP Working Group 4", performed two collaborative studies examining the use of USP Calibrator Tablets for apparatus suitability testing of USP Apparatus 4.

Two basic principles are applied for in vitro dissolution testing: the "stirred beaker" methods and the "flow through" procedures.

The "stirred beaker" methods place the dosage unit in a fixed volume in a vessel and the stirring provides mechan- ical agitation. The rotating basket and the paddle devices (Apparatus 1 and 2 of the USP) are simple, robust and adequately standardized. Another advantage of these two devices is that they can be easily automated, which is important for routine investigations. Therefore, the use of these devices is recommended in various guidelines as the first choice for the in vitro dissolution testing of immediate release dosage forms. Nevertheless, some difficulties may arise when a $\mathrm{pH}$ change/media change during investigation is desired, or when poorly soluble drugs are to be investigated. Furthermore, the hydrodynamics in the paddle apparatus are very complex and vary with site of the dosage form in the vessel. These variations may significantly affect the drug dissolution, should the dosage form position in the vessel vary due to sticking or floating.

Another system is the reciprocating cylinder device (Apparatus type 3 of USP), the design of which is based on the disintegration tester as an alternative to the basket and

\section{Table 1. List of participating laboratory of the $1^{\text {st }}$ Collaborative Study}

\begin{tabular}{|lll|}
\hline Laboratory code & Participating laboratory & Location \\
\hline Laboratory 1 & Hoechst AG & Frankfurt, Germany \\
\hline Laboratory 2 & The United States Pharmacopeia & Rockville, USA \\
\hline Laboratory 3 & The United States Food and Drug Administration & Rockville, USA \\
\hline Laboratory 4 & Zentrallaboratorium Deutscher Apotheker & Eschborn, Germany \\
\hline Laboratory 5 & Bayer & Leverkusen, Germany \\
\hline Laboratory 6 & Medical Products Agency,Biopharmaceutics Division & Uppsala,Sweden \\
\hline Laboratory 7 & Laboratoire de Biopharmacie, Faculté der Pharmacie & Clermont-Ferrand, France \\
\hline
\end{tabular}

Table 2. List of participating laboratory of the $2^{\text {nd }}$ Collaborative Study

\begin{tabular}{|lll|}
\hline Laboratory code & Participating laboratory & Location \\
\hline Laboratory 1 & Hoechst AG & Frankfurt, Germany \\
\hline Laboratory 2 & Medical Products Agency, Biopharmaceutics Division & Uppsala, Sweden \\
\hline Laboratory 3 & The United States Food and Drug Administration & Rockville, USA \\
\hline Laboratory 4 & The United States Pharmacopeia & Rockville, USA \\
\hline Laboratory 5 & Zentrallaboratorium Deutscher Apotheker & Eschborn, Germany \\
\hline Laboratory 6 & Deutsches Arzneiprüfinstitut & Eschborn, Germany \\
\hline
\end{tabular}

paddle apparatus. Finally; with the "flow through cell" apparatus (Apparatus type 4 of the USP) the dosage unit is continuously flushed with a stream of fluid, simultaneously providing the medium and the mechanical agitation to facilitate dissolution of the drug. The flow through cell apparatus is designed for the dissolution testing of poorly soluble drug products, powders, granules and some special dosage forms such as lipidbased suppositories or implants.

All of these dissolution devices are described in the Pharmacopeias, including the USP and the European, British, International, and Japanese Pharmacopeia. In order to obtain meaningful dissolution data and to yield reproducible 
results, even when the test is performed in different laboratories and by different analysts, all variables that could have an influence on the test should be identified and the extent of their effect evaluated. There are many apparatus related factors that can affect in vitro dissolution (1). Therefore, for comparable dissolution results, the use of suitable, welldefined and appropriately qualified equipment is of great importance. As a result of international harmonization, the design of the dissolution devices most frequently used for oral dosage forms (USP Apparatus 1-4) is nowadays concordant worldwide and USP's apparatus suitability test are used globally.

The history of the USP Apparatus 4 is extensively described in the book Dissolution Testing of Oral Dosage Forms, (2). The use of instruments in the GMP environment

\section{Table 3. Study protocol of the $1^{\text {st }}$ Collaborative Study}

\begin{tabular}{|l|l|}
\hline Parameter & Settings \\
\hline Test material & Prednisone USP Tablets, lot K \\
\hline Pump & Piston pump $120 \pm 10$ pulses $/ \mathrm{min}$ \\
\hline Cell type & $12 \mathrm{~mm}$ and $22.6 \mathrm{~mm}$ tablet flow through cell \\
\hline Flow rate $12 \mathrm{~mm}$ cell & $8 \mathrm{~mL} / \mathrm{min}, 16 \mathrm{~mL} / \mathrm{min}$, and $32 \mathrm{~mL} / \mathrm{min}$ \\
\hline Flow rate $22.6 \mathrm{~mm}$ cell & $\begin{array}{l}16 \mathrm{~mL} / \mathrm{min}, 32 \mathrm{~mL} / \mathrm{min} \text {, and } 50 \mathrm{~mL} / \mathrm{min} \\
\text { additionally: } \mathrm{non} \text {-de-aerated dissolution } \\
\text { medium at } 32 \mathrm{~mL} / \mathrm{min}\end{array}$ \\
\hline Tablet holder & None \\
\hline Medium & de-ionized water \\
\hline Filter & Whatman GF/F $(0.7 \mu \mathrm{m})$ \\
\hline Sampling time & 30,60, and $120 \mathrm{minutes}$ \\
\hline
\end{tabular}

Table 4. Study protocol of the $2^{\text {nd }}$ Collaborative Study

\begin{tabular}{|l|l|}
\hline Parameter & Settings \\
\hline Test material & Salicylic Acid USP Tablets, Lot M \\
\hline Pump & Piston pump $120 \pm 10$ pulses $/ \mathrm{min}$ \\
\hline Cell type & $12 \mathrm{~mm}$ and $22.6 \mathrm{~mm}$ tablet flow through cell \\
\hline Flow rate $12 \mathrm{~mm}$ cell & $8 \mathrm{~mL} / \mathrm{min}, 16 \mathrm{~mL} / \mathrm{min}$, and $32 \mathrm{~mL} / \mathrm{min}$ \\
\hline Flow rate $22.6 \mathrm{~mm}$ cell & $\begin{array}{l}16 \mathrm{~mL} / \mathrm{min}, 32 \mathrm{~mL} / \mathrm{min} \text {, and } 50 \mathrm{~mL} / \mathrm{min} \\
\text { additionally: } \mathrm{non} \text {-de-aerated dissolution } \\
\text { medium at } 32 \mathrm{~mL} / \mathrm{min}\end{array}$ \\
\hline Tablet holder & tablet holder according to USP \\
\hline Medium & $\begin{array}{l}\text { deaerated } 0.05 \mathrm{M} \text { phosphate buffer solution } \\
\text { pH } 7.4\end{array}$ \\
\hline Filter & Whatman GF/F $(0.7 \mu \mathrm{m})$ \\
\hline Sampling time & $30,60,120$, and 240 minutes \\
\hline
\end{tabular}

requires thorough qualification and requalification, called apparatus suitability tests. These tests have to be repeated after regular intervals. The USP provides tablets which were introduced to detect deviations from pharmacopeial mounting, operating or evaluating of the pharmacopeial instruments, mainly vibration. They do exist as disintegrating prednisone, non-disintegrating salicylic acid tablets for Apparatus 1 and 2. As of now, no pharmacopeial reference formulation is available for USP Apparatus 4.

The purpose of the study initiated by FIP's Working Group 4 , was to evaluate the suitability of prednisone and salicylic acid tablets for apparatus suitability test of USP Apparatus 4.

\section{Experimental setup \\ Study protocol}

Investigations with both USP tablets, prednisone and salicylic acid, were performed and are independently part of two separate collaborative studies. The flow through cell apparatus used by participating laboratories had to comply with the mechanical specifications as stated in the USP. Investigations were performed with both cell types, i.e. 12$\mathrm{mm}$ and 22.6- $\mathrm{mm}$ flow through cell, stipulated in the USP. The pump required for the investigations was a piston pump operated at 120 pulses $/ \mathrm{min}$ ( \pm 10 pulses $/ \mathrm{min}$ ).

The participants were requested to submit the individual results of the dissolution tests for each investigational setup expressed as percentage of drug dissolved at the defined sampling time point.

$7^{\text {st }}$ Collaborative Study—Prednisone Tablets: Each laboratory used the USP Prednisone tablets, Lot K as donated from USP.

A study protocol was executed including seven control laboratories. The participating laboratories are listed in Table 1.

Analysts were asked to carry out the dissolution run sixfold in parallel. The experimental settings are listed in Table 3.

2nd Collaborative Study —Salicylic Acid:Each laboratory used USP Salicylic Acid Tablets, Lot M.

A study protocol was executed including six control laboratories. The participating laboratories are listed in Table 2. The experimental settings are listed in Table 4.

\section{Method of data analysis}

Individual data were submitted to the coordinators. The results which were generated under conditions that did not meet the protocol were excluded from statistical evaluation. Mainly, inconsistency in flow-rate was the reason for dropouts. The fractionated data were computed as percent dissolved of label claim for individual tablets. The results were analyzed by statistics with regard to the procedure applied by PhRMA (2). Two sided confidence interval for $1-\alpha=0.975$ were computed. After analysis of variance, the limits of acceptability were expressed as the grand mean $\pm 2.2414 \mathrm{~S}$.

\section{Results}

$1^{\text {st }}$ Collaborative Study—Prednisone Tablets - disintegrating tablets 


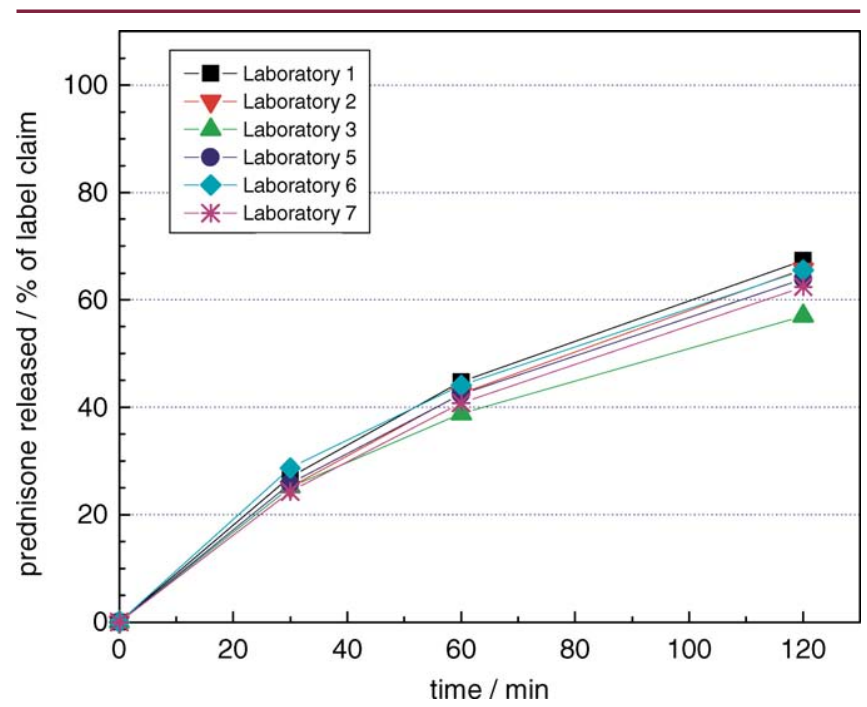

Figure 1. In vitro dissolution behavior of Prednisone Tablets, Lot K. Flowthrough cell apparatus, 12-mm cell type, deaerated, deionized water, 8 $\mathrm{ml} / \mathrm{min}, 37^{\circ} \mathrm{C}$. Arithmetic means ( $\left.n=6\right)$.

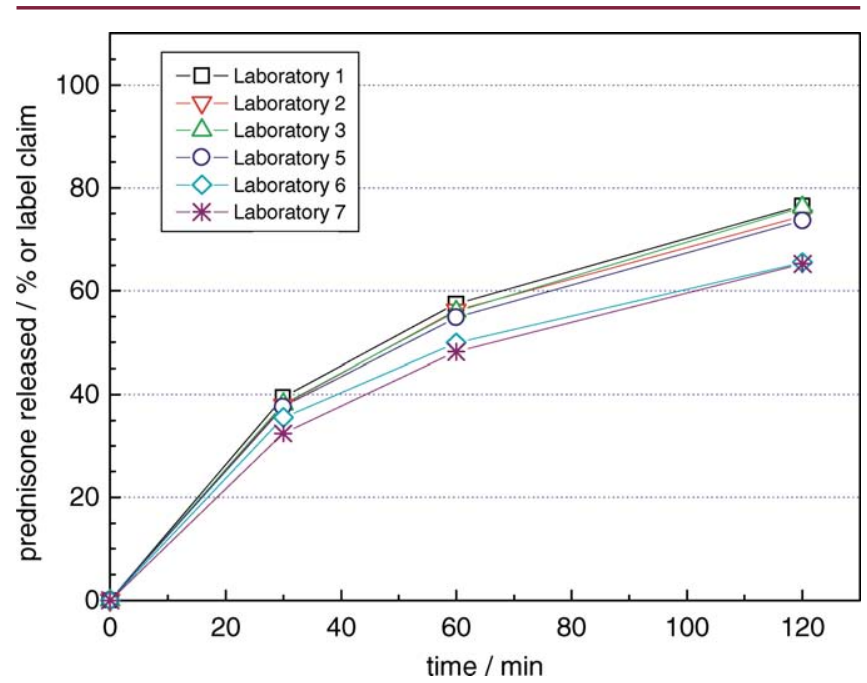

Figure 2. In vitro dissolution behavior of Prednisone Tablets, lot K. Flowthrough cell apparatus, 12-mm cell type, deaerated, deionized water, 16 $\mathrm{mL} / \mathrm{min}, 37^{\circ} \mathrm{C}$. Arithmetic means ( $\left.n=6\right)$.

\section{Cell type: $12 \mathrm{~mm}$}

The results for the prednisone study with the 12-mm flow through cell are displayed in Figures 1 to 3 .

The scatter of individual results, exemplified for the 30 minute values, of individual tablets investigated in different labs are displayed in Figure 4.

The results presented in Figures 1 to 3 show a small inter-lab variability at all given flow rates. The slope of all profiles is comparable and no great influence of flow rate on dissolution rate could be observed. Although the cumulative profiles were computed from fractionated data with an inherent propagation of errors the intraand inter-lab variability was determined not to be unexpectedly high in comparison to data sets published for collaborative studies performed with USP Prednisone and USP Apparatus 1 or 2 . The 12-mm flow through cell

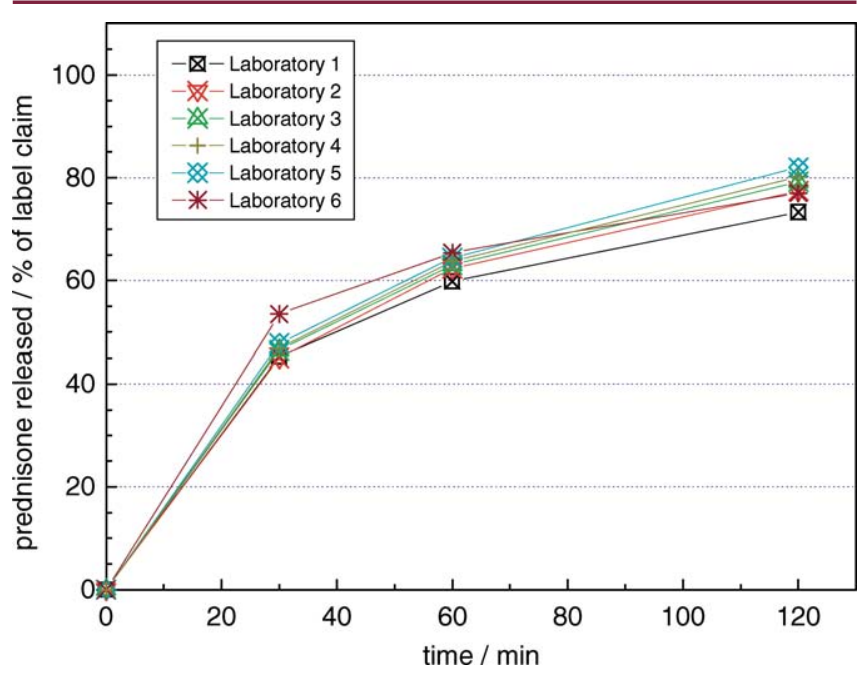

Figure 3. In vitro dissolution behavior of Prednisone Tablets, Lot K. Flowthrough cell apparatus, 12- $\mathrm{mm}$ cell type, deaerated, deionized water, 32 $\mathrm{mL} / \mathrm{min}, 37^{\circ} \mathrm{C}$. Arithmetic means ( $\left.n=6\right)$.

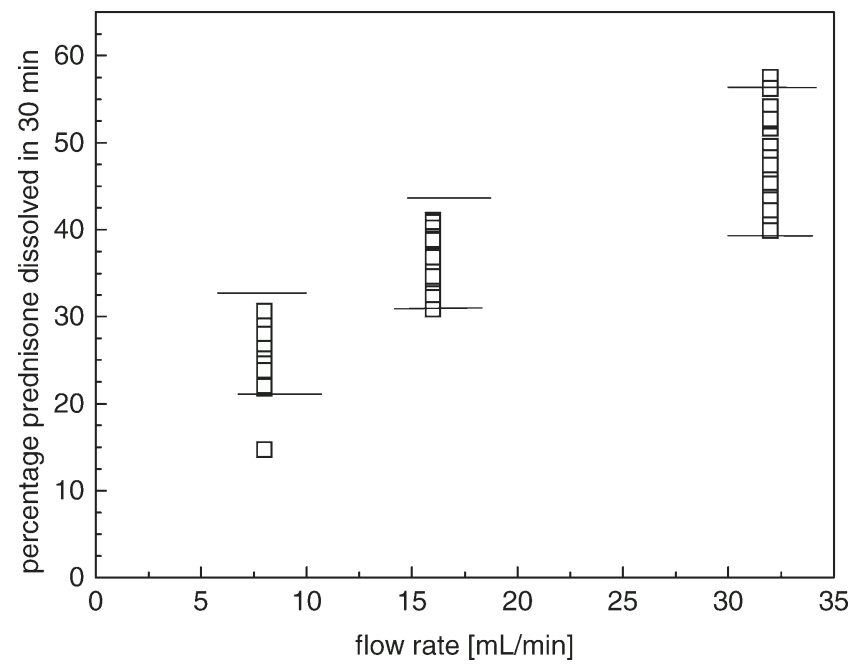

Figure 4. Individual results of Prednisone Tablets, lot $K$, at 30 minutes sampling time point obtained from all different laboratories. Flow-through cell apparatus, $12-\mathrm{mm}$ cell type, deaerated, deionized water, $37^{\circ} \mathrm{C}$.

may be attributed to low variability of dissolution results.

\section{Cell type: $22.6 \mathrm{~mm}$}

The results for the prednisone study were generated with operating the instrument under the conditions given in Table 3. They are displayed in Figure 5 to Figure 7 for the use of the 22.6-mm cell type. Figure 8 shows the results of the investigations of Prednisone Tablets by using non-deaerated deionized water as dissolution medium at $32 \mathrm{~mL} / \mathrm{min}$.

The scatter of individual results, exemplified for the 30 minute values, of individual tablets investigated in different labs are displayed in Figure 9.

The results presented in Figures 6 and 7 show a small inter-lab variability at the given flow rates. The slope of all profiles is comparable and no great influence of flow rate on 


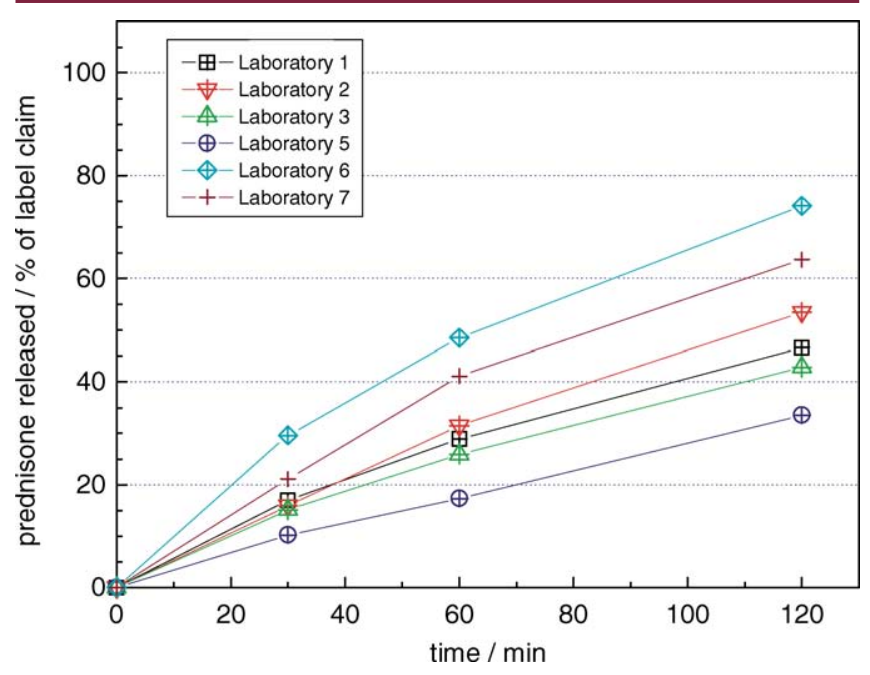

Figure 5. In vitro dissolution behavior of Prednisone Tablets, Lot K. Flowthrough cell apparatus, 22.6-mm cell type, deaerated, deionized water, 16 $\mathrm{mL} / \mathrm{min}, 37^{\circ} \mathrm{C}$. Arithmetic means $(n=6)$.

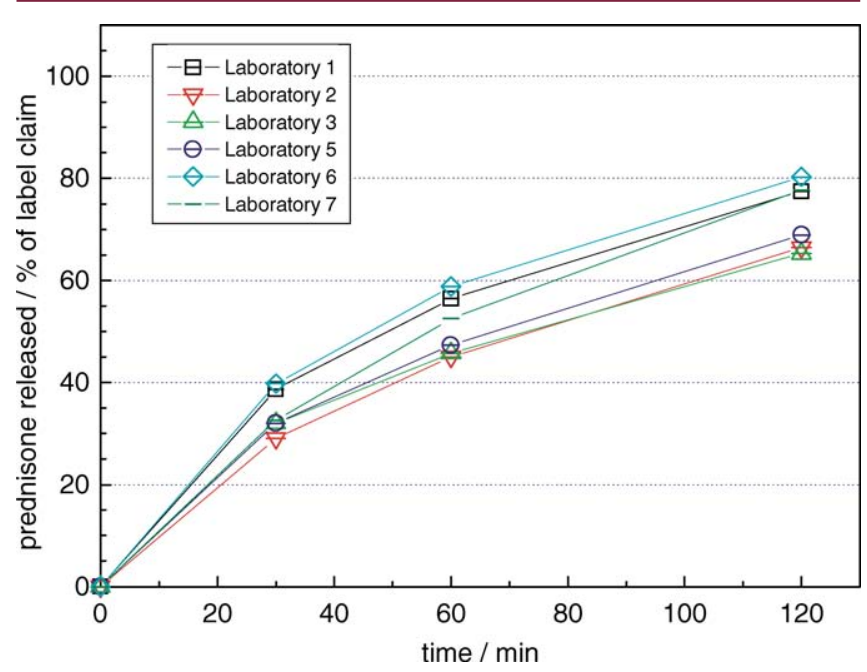

Figure 6. In vitro dissolution behavior of Prednisone Tablets, lot K. Flowthrough cell apparatus, 22.6- $\mathrm{mm}$ cell type, deaerated, deionized water, 32 $\mathrm{ml} / \mathrm{min}, 37^{\circ} \mathrm{C}$ Arithmetic means ( $n=6$ ).

dissolution rate could be observed. Although the cumulative profiles were computed from fractionated data with an inherent propagation of errors the intra- and inter-lab variability was determined not to be unexpectedly high in comparison to data sets published for collaborative studies performed with USP prednisone and USP Apparatus 1 or 2 . The $22.6 \mathrm{~mm}$-cell may be attributed to low variability of dissolution results.

In contrast the low flow rate of $16 \mathrm{~mL} / \mathrm{min}$ caused high inter- and intra-lab variability as can be derived from Figure 5. The comparison of the results depicted in Figures 6 and 8 shows an increase in variability when the medium was not deaerated. The observations made with the use of the nondeaerated fluid were that air bubbles stuck in the cylinders of the piston pump created compressible volumes and hence variability in flow rates.

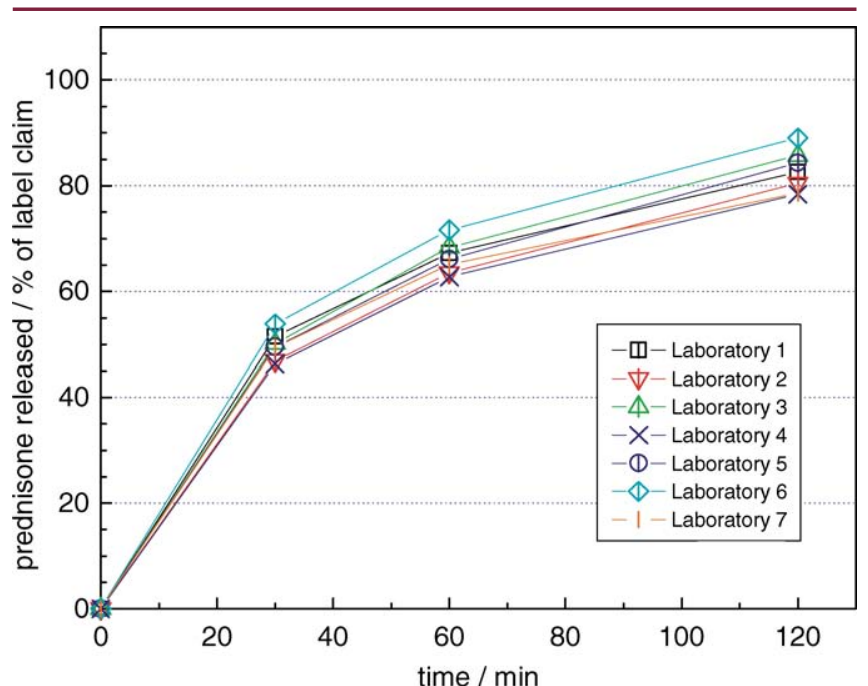

Figure 7. In vitro dissolution behavior of Prednisone Tablets, Lot K. Flowthrough cell apparatus, 22.6- $\mathrm{mm}$ cell type, deaerated, deionized water, 50 $\mathrm{mL} / \mathrm{min}, 37^{\circ} \mathrm{C}$. Arithmetic means $(n=6)$.

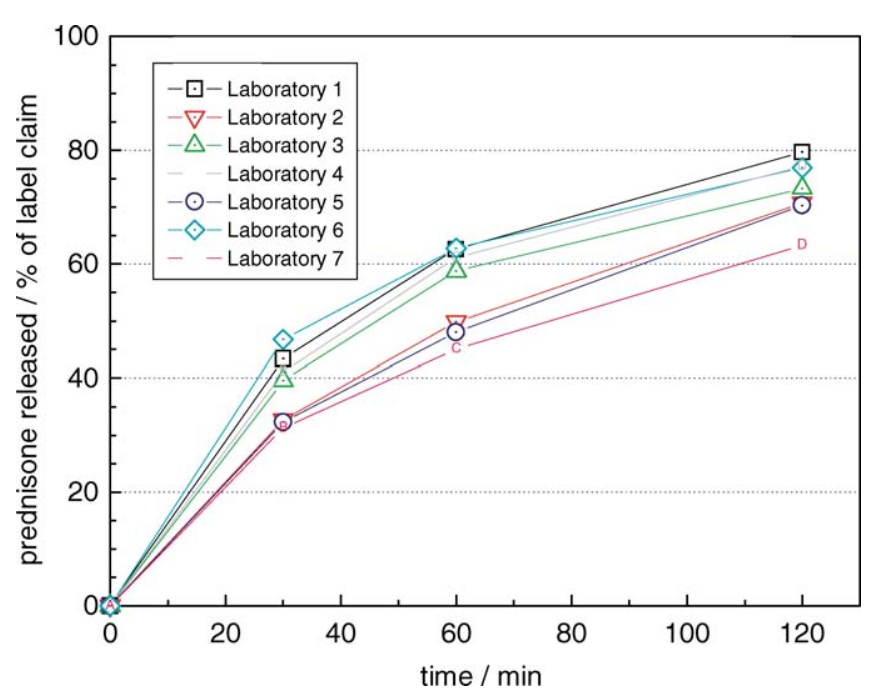

Figure 8. In vitro dissolution behavior of Prednisone Tablets, Lot K. Flowthrough cell apparatus, 22.6-mm cell type, non-deaerated, deionized water, $32 \mathrm{ml} / \mathrm{min}, 37^{\circ} \mathrm{C}$. Arithmetic means ( $\left.n=6\right)$.

$2^{\text {nd }}$ Collaborative Study - Salicylic Acid Tablets - non-disintegrating tablets

Cell type: $12 \mathrm{~mm}$

The results for the salicylic acid study were generated operating the instrument under the conditions given in Table 4. They are displayed in Figure 10 to Figure 12 for the use with the $12 \mathrm{~mm}$ cell.

The individual results for each individual tablet investigated in different labs are displayed in Figure 13.

The results presented in Figures 10 to 12 show a small inter-lab variability at all given flow rates. The slope of all profiles is comparable and an influence of flow rate on dissolution rate could be observed. However, as derived from the slopes of the zero-order dissolution kinetics, no proportionality between flow rate and dissolution rate was 


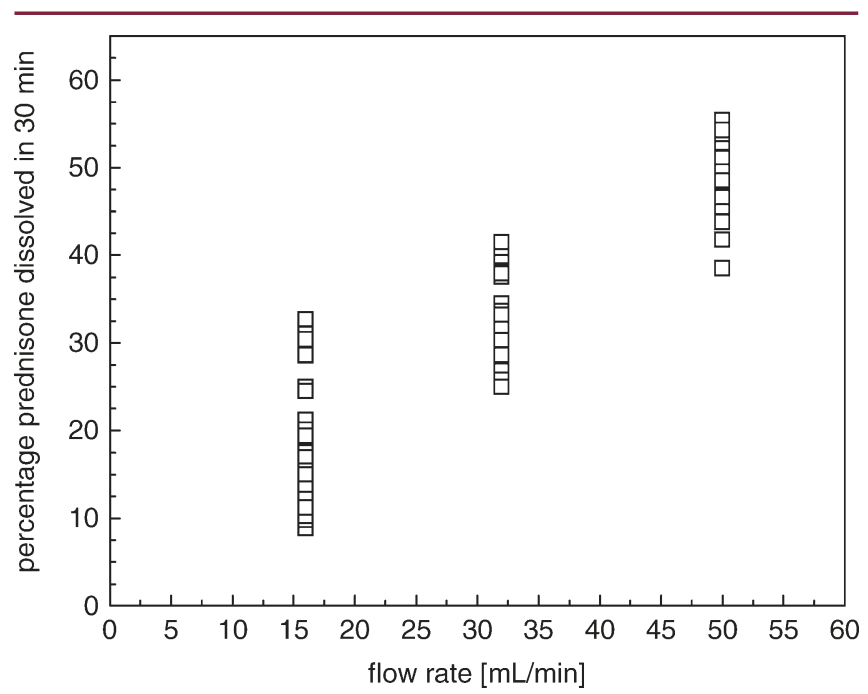

Figure 9. Individual results of Prednisone Tablets, Lot K, at 30 minutes sampling time point obtained from the different laboratories. Flow-through cell apparatus, $22.6 \mathrm{~mm}$ cell type, deaerated, deionized water, $37^{\circ} \mathrm{C}$.

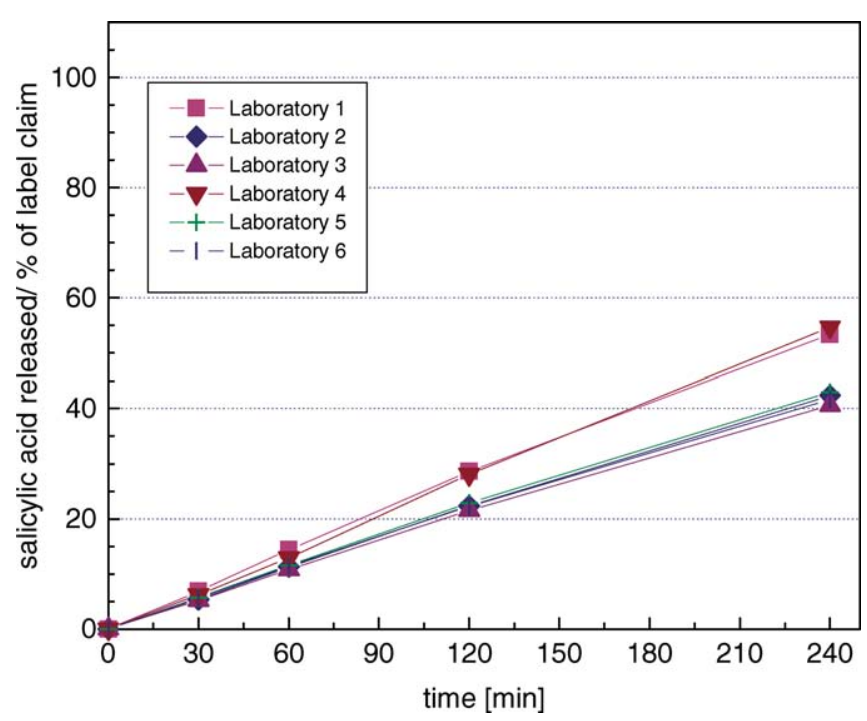

Figure 10. In vitro dissolution behavior of Salicylic Acid Tablets, Lot M. Flowthrough cell apparatus, $12 \mathrm{~mm}$ cell type, deaerated $0.05 \mathrm{M}$ phosphate buffer solution $\mathrm{pH} 7.4,8 \mathrm{~mL} / \mathrm{min}, 37^{\circ} \mathrm{C}$. Arithmetic means $(n=6)$.

detectable. Although the cumulative profiles were computed from fractionated data with an inherent propagation of errors the intra- and inter-lab variability was determined not to be unexpectedly high in comparison to data sets published for collaborative studies performed with USP salicylic acid and USP Apparatus 1 or 2. The 12-mm flow through cell may be attributed to a generally low variability of dissolution results with a slight increase of variability with increase of flow rate.

\section{Cell type: $22.6 \mathrm{~mm}$}

The results for the salicylic acid study were generated operating the instrument under the conditions given in Table 4. They are displayed in Figure 14 to Figure 16 for the use of the 22.6-mm flow through cell type. Figure 17 shows

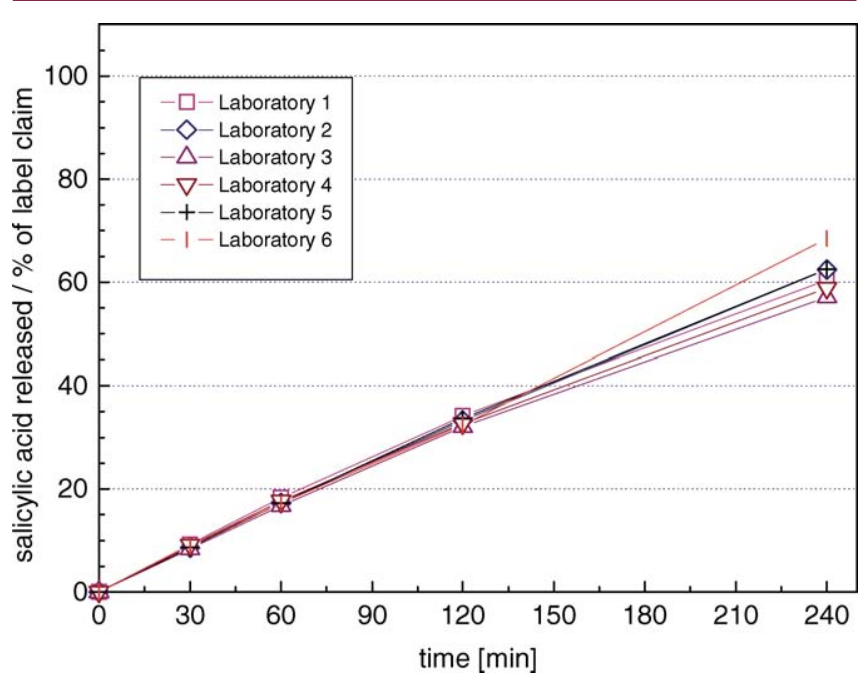

Figure 11. In vitro dissolution behavior of Salicylic Acid Tablets, Lot M. Flowthrough cell apparatus, $12-\mathrm{mm}$ cell type, deaerated $0.05 \mathrm{M}$ phosphate buffer solution $\mathrm{pH} 7.4,16 \mathrm{~mL} / \mathrm{min}, 37^{\circ} \mathrm{C}$. Arithmetic means ( $\left.n=6\right)$.

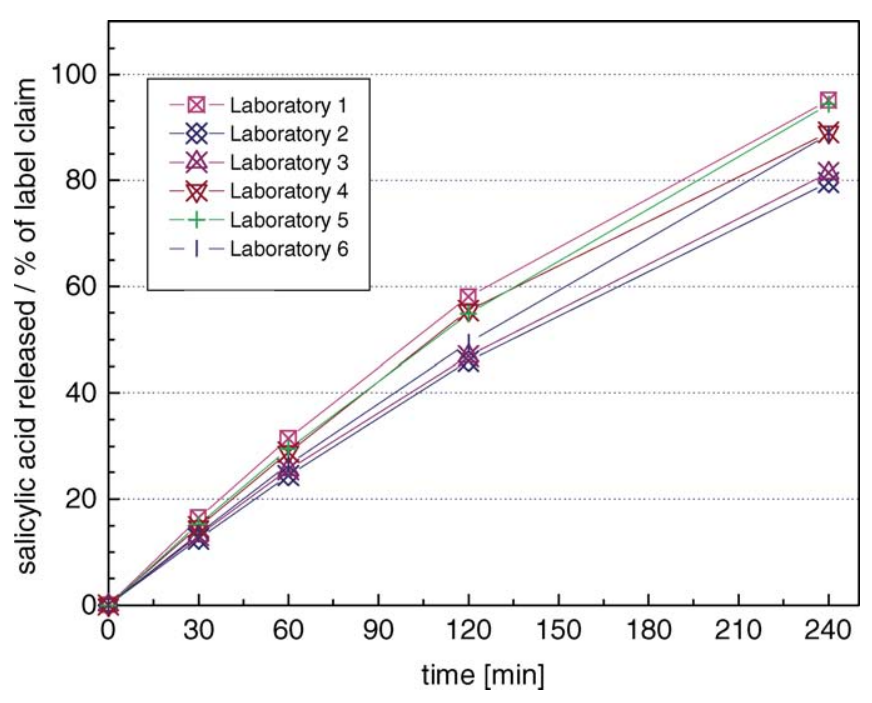

Figure 12. In vitro dissolution behavior of Salicylic Acid Tablets, Lot M. Flowthrough cell apparatus, 12- $\mathrm{mm}$ cell type, deaerated $0.05 \mathrm{M}$ phosphate buffer solution $\mathrm{pH} 7.4,32 \mathrm{~mL} / \mathrm{min}, 37^{\circ} \mathrm{C}$. Arithmetic means ( $\left.n=6\right)$.

the results of the investigations of Salicylic Acid Tablets by using of non-deaerated phosphate buffer solution $\mathrm{pH} 7.4$ as dissolution medium at $32 \mathrm{~mL} / \mathrm{min}$.

The individual results for each individual tablet investigated in different labs are displayed in Figure 18.

The results presented in Figures 14 to 17 show a small interlab variability at all given flow rates. The slope of all profiles is comparable and no systematic influence of flow rate on dissolution rate could be observed. However, as derived from the slopes of the zero-order dissolution kinetics, no proportionality between flow rate and dissolution rate was detectable. Although the cumulative profiles were computed from fractionated data with an inherent propagation of errors the intra- and inter-lab variability was determined not to be unexpectedly high in comparison to data sets published for collab- 


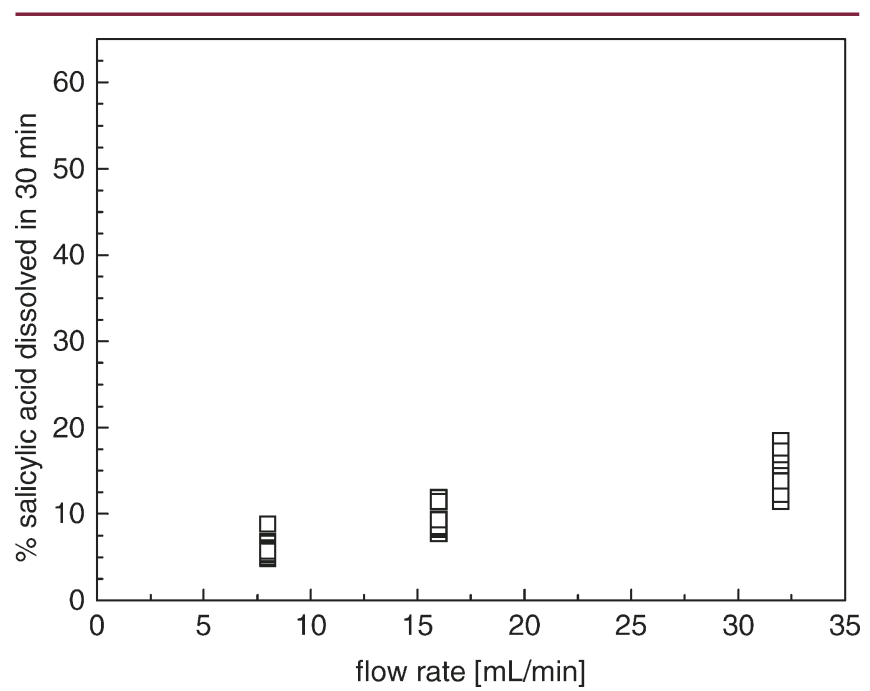

Figure 13. Individual results of Salicylic Acid Tablets, Lot M, at 30 minutes sampling time point obtained from the different laboratories. Flow-through cell apparatus, 12-mm cell type, deaerated $0.05 \mathrm{M}$ phosphate buffer solution $\mathrm{pH} 7.4,37^{\circ} \mathrm{C}$.

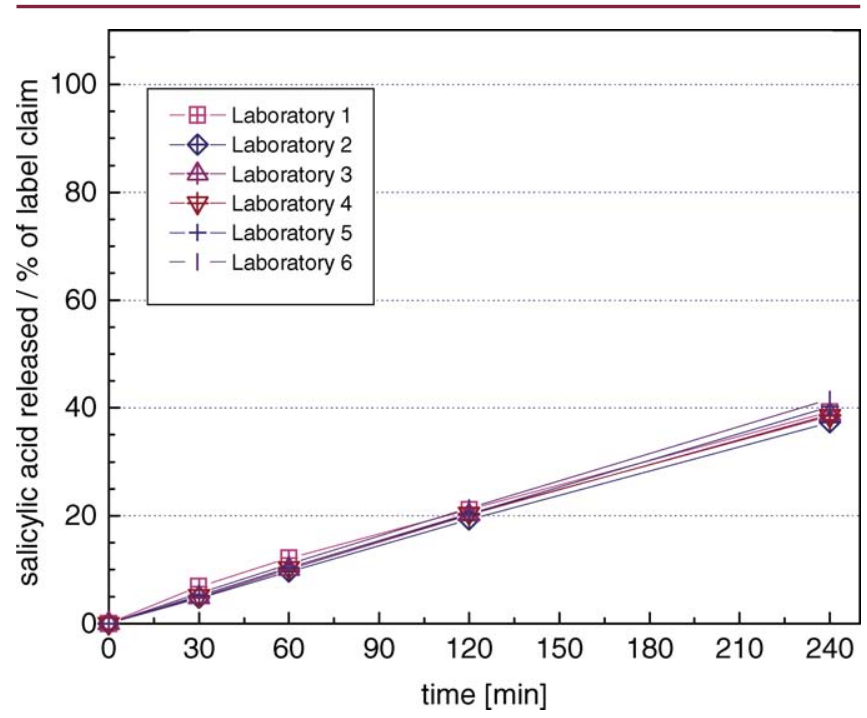

Figure 14. In vitro dissolution behavior of Salicylic Acid Tablets, Lot M. Flowthrough cell apparatus, 22.6-mm cell type, deaerated $0.05 \mathrm{M}$ phosphate buffer solution $\mathrm{pH} 7.4,16 \mathrm{~mL} / \mathrm{min}, 37^{\circ} \mathrm{C}$. Arithmetic means ( $\left.n=6\right)$.

orative studies performed with USP salicylic acid tablets and USP Apparatus 1 or 2. The 22.6-mm flow through cell may be attributed to a generally low variability of dissolution results with a slight increase of variability with increase of flow rate. From the data shown in Figure 18 neither the dissolution rate nor the variability of results were influenced by the flow rate.

\section{Conclusions}

The USP reference formulations were quite suitable to prove the correct handling of the instrument and the correct treatment of data. For both formulations it was found that differences in flow rate did cause little and certainly no proportional effects on the dissolution rate. For salicylic acid tablets and the 22.6-mm flow through cell, flow rate changes had no influence on the outcome of the results.

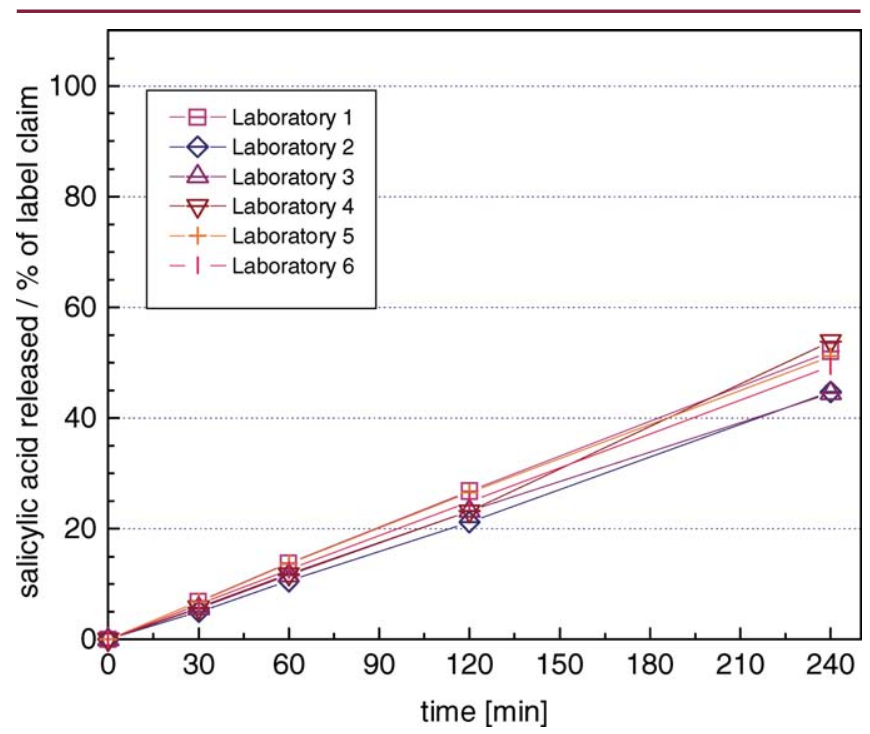

Figure 15. In vitro dissolution behavior of Salicylic Acid Tablets, Lot M. Flowthrough cell apparatus, 22.6- $\mathrm{mm}$ cell type, deaerated $0.05 \mathrm{M}$ phosphate buffer solution $\mathrm{pH} 7.4,32 \mathrm{~mL} / \mathrm{min}, 37^{\circ} \mathrm{C}$. Arithmetic means ( $\left.n=6\right)$.

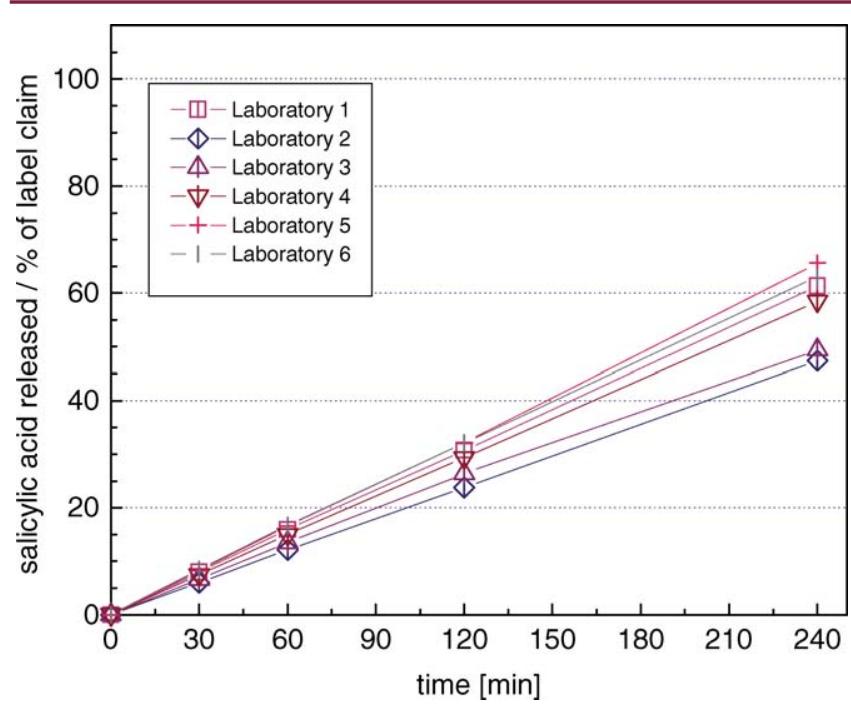

Figure 16. In vitro dissolution behavior of Salicylic Acid Tablets, Lot M. Flowthrough cell apparatus, 22.6- $\mathrm{mm}$ cell type, deaerated $0.05 \mathrm{M}$ phosphate buffer solution $\mathrm{pH} 7.4,50 \mathrm{~mL} / \mathrm{min}, 37^{\circ} \mathrm{C}$. Arithmetic means ( $\left.n=6\right)$.

Air entrapped in the dissolution medium was found not to change significantly the dissolution pattern. However, some influence caused by compressible volumes in the piston pump changed the flow rate.

The USP reference standard tablet formulations were developed with the goal to detect unwanted agitation such as vibrations. Their sensitivity towards vibrations generated by the dissolution instruments' paddle and basket is as well proven as their sensitivity towards mechanical interferences with air bubbles in the dissolution medium. The very mild hydrodynamic conditions in the flow through cell instrument seem not to reach the level of disturbances needed to largely influence the dissolution mechanics and/or rates of the USP reference formulations.

Instead their use is to evaluate by a commonly used tech- 


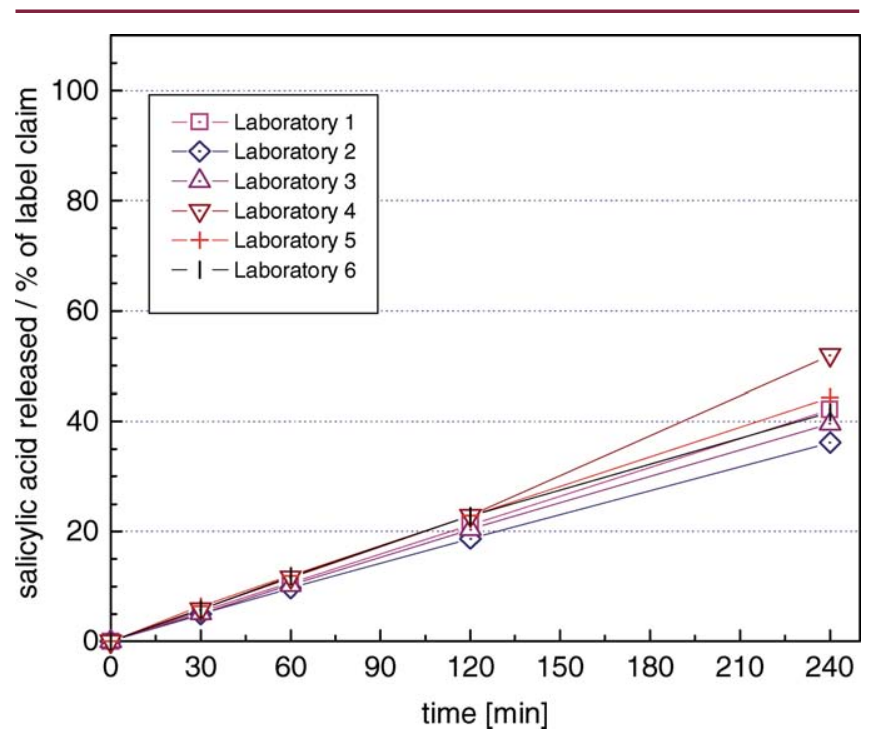

Figure 17. In vitro dissolution behavior of Salicylic Acid Tablets, Lot M. Flowthrough cell apparatus, 22.6- $\mathrm{mm}$ cell type, non-deaerated $0.05 \mathrm{M}$ phosphate buffer solution $\mathrm{pH} 7.4,32 \mathrm{~mL} / \mathrm{min}, 37^{\circ} \mathrm{C}$. Arithmetic means $(n=6)$.

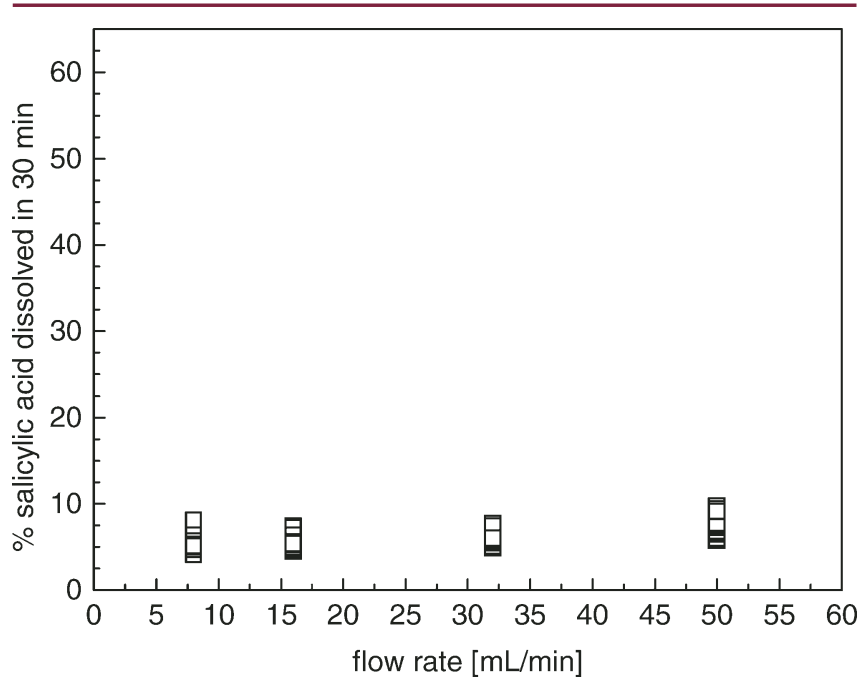

Figure 18. Individual results of Salicylic Acid Tablets, lot M, at 30 minutes sampling time point obtained from the different laboratories. Flowthrough cell apparatus, 22.6-mm cell type, deaerated $0.05 \mathrm{M}$ phosphate buffer solution $\mathrm{pH} 7.4,37^{\circ} \mathrm{C}$.

nique and procedure that the whole system comprising the pump, the cells and the sampling unit, and last, but not least the analyst, is capable of generating fractionated data. This may not be trivial because primarily fractions of dissolution versus fraction of times are generated and have to be transformed in cumulative curves. This is necessary to provide comparability with data generated with closed systems such as USP Apparatus 1 and 2.

Moreover, if correctly mounted and operated and, most importantly, at an accurate and precise flow rate, the flow through cell instrument allows the generation of dissolution and drug release data with very low inter- and intra-lab variability. This allows clear characterization of the biopharmaceutical properties of a broad variety of pharmaceutical preparations.

\section{References}

1. Gray, V.A., Drug Release Calibrators for Apparatus 3 Collaborative Study Results, Pharm. Forum 20, I (1994), 6934-6943

2. Dressman, Krämer, eds. Dissolution Testing of Oral Dosage Forms, published by Marcel Dekker, New York, 2005.

3. Hanson, R and Gray V, Handbook of Dissolution Testing, Third Edition, 2004, published by Dissolution Technologies, Inc., Hockessin, DE. 